\title{
Functional and physical interactions between P2Y receptors and ion channels
}

\author{
Hend Gafar, Giri K Chandaka, Stefan Boehm \\ From 18th Scientific Symposium of the Austrian Pharmacological Society (APHAR). Joint meeting with the \\ Croatian, Serbian and Slovenian Pharmacological Societies. \\ Graz, Austria. 20-21 September 2012
}

\section{Background}

Neuronal P2Y receptors, i.e. nucleotide-sensitive G protein-coupled receptors (GPCRs), are known to control various voltage-gated ion channels, in particular $\mathrm{K}_{\mathrm{V}} 7 \mathrm{~K}^{+}$ and $\mathrm{Ca}_{\mathrm{V}} 2.2 \mathrm{Ca}^{2+}$ channels. The differential modulation of these ion channels via GPCRs was shown to rely on the presence or absence of scaffolding proteins such as AKAP79/150 and NHERF-2. Since scaffold proteins are believed to bring GPCRs and ion channels in close proximity to guarantee efficient $G$ protein-mediated modulation, this project evaluates whether a tight contact between P2Y receptors and ion channels is a prerequisite for their functional interaction.

\section{Methods}

$\mathrm{P}_{2} \mathrm{Y}_{1}$ or $\mathrm{P}_{2} \mathrm{Y}_{12}$ receptors with fluorescent tags (CFP or YFP) were expressed together with fluorescently labeled $\mathrm{K}_{\mathrm{V}} 7.2 / 7.3$ or $\mathrm{Ca}_{\mathrm{V}} 2.2$ channels in tsA 201 cells and the channel modulation by nucleotides was determined by measuring the according currents. To evaluate the behavior of the receptors and channels in the membrane, fluorescence recovery after photobleaching (FRAP) was determined by confocal laser microscopy.

\section{Results}

Activation of $\mathrm{P}_{2} \mathrm{Y}_{1}$ but not of $\mathrm{P}_{2} \mathrm{Y}_{12}$ receptors by ADP inhibited the $\mathrm{K}^{+}$currents in a concentration-dependent manner by up to $20.5 \pm 1.9 \%$. Conversely, activation of both, $\mathrm{P}_{2} \mathrm{Y}_{1}$ and $\mathrm{P}_{2} \mathrm{Y}_{12}$ receptors, reduced the $\mathrm{Ca}^{2+}$ currents by up to $60.1 \pm 7.4 \%$ and $76.3 \pm 4.2 \%$, respectively. In initial FRAP experiments, the YFP-labeled receptors showed similar half-times of around 80 seconds. Upon coexpression of the $\mathrm{P}_{2} \mathrm{Y}_{1}$ receptor with the $\mathrm{K}_{\mathrm{V}} 7$ channel the half-time increased significantly $(\mathrm{p}<0.009)$ to $116 \mathrm{sec}-$ onds compared to single expression of receptor or channel only. In the case of $\mathrm{P} 2 \mathrm{Y}_{12}$, coexpression with $\mathrm{K}_{\mathrm{V}} 7$ showed no significant change compared to $\mathrm{P}_{2} \mathrm{Y}_{12}$ or $\mathrm{K}_{\mathrm{V}} 7$ alone.

\section{Conclusions}

These findings suggest that distinct ion channels are modulated by different $\mathrm{P} 2 \mathrm{Y}$ receptors. $\mathrm{K}_{\mathrm{V}} 7$ currents are inhibited by $\mathrm{P}_{2} \mathrm{Y}_{1}$ whereas $\mathrm{Ca}_{\mathrm{V}} 2.2$ currents are reduced by both $\mathrm{P}_{2} \mathrm{Y}_{1}$ and $\mathrm{P} 2 \mathrm{Y}_{12}$. Additionally, FRAP data show that the presence of $\mathrm{K}_{\mathrm{V}} 7$ slows down the movement of $\mathrm{P}^{2} \mathrm{Y}_{1}$ in the membrane, but not that of $\mathrm{P}_{2} \mathrm{Y}_{12}$. This suggests that there is a physical interaction between $\mathrm{P}_{2} \mathrm{Y}_{1}$ and $\mathrm{K}_{\mathrm{V}} 7$ which is not present between $\mathrm{P}_{2} \mathrm{Y}_{12}$ and $\mathrm{K}_{\mathrm{V}} 7$. The influence on movement of $\mathrm{P}_{2} \mathrm{Y}_{1}$ and $\mathrm{P} 2 \mathrm{Y}_{12}$ receptors in the membrane by the presence $\mathrm{Ca}_{\mathrm{V}} 2.2$ remains to be elucidated.

\section{Acknowledgements \\ This study is supported by the FWF-funded doctoral program CCHD (W1205).}

Published: 17 September 2012

doi:10.1186/2050-6511-13-S1-A61

Cite this article as: Gafar et al.: Functional and physical interactions

between P2Y receptors and ion channels. BMC Pharmacology and Toxicology 2012 13(Suppl 1):A61.

\footnotetext{
* Correspondence: stefan.boehm@meduniwien.ac.at

Department of Neurophysiology and Neuropharmacology, Center for

Physiology and Pharmacology, Medical University of Vienna, 1090 Vienna, Austria
}

(c) 2012 Gafar et al; licensee BioMed Central Ltd. This is an Open Access article distributed under the terms of the Creative Commons Attribution License (http://creativecommons.org/licenses/by/2.0), which permits unrestricted use, distribution, and reproduction in any medium, provided the original work is properly cited. 